Jurnal Kejuruteraan SI 1(4) 2018: 51-58

http://dx.doi.org/10.17576/jkukm-2018-si1(4)-07

\title{
Physical and Chemical Cleaning for Nanofiltration/Reverse Osmosis (NF/RO) Membranes in Treatment of Tertiary Palm Oil Mill Effluent (POME) for Water Reclamation
}

(Pembersihan Fizikal dan Kimia untuk Membran NF/RO dalam Rawatan Kumbahan Kilang Minyak Kelapa Sawit (POME) untuk Penebusgunaan Air)

\author{
Teow Yeit Haan ${ }^{\mathrm{a}, \mathrm{b}^{*}}$, Mohd Syahmi Hafizi Ghani ${ }^{\mathrm{a}}$, Abdul Wahab Mohammad ${ }^{\mathrm{a}, \mathrm{b}}$ \\ ${ }^{a}$ Chemical Engineering Program, \\ ${ }^{b}$ Research Centre for Sustainable Process Technology, \\ Faculty of Engineering and Built Environment, Universiti Kebangsaan Malaysia
}

\begin{abstract}
Treatment of palm oil mill effluent (POME) with membranes can cause membrane fouling due to the presence of suspended solids and organic matters. The objective of this paper is to evaluate the performance of three types of membranes (NF270, $X L E$, and BW30) after the physical and chemical cleaning. Continuous chemical cleaning was conducted with NaOH and with $\mathrm{HCl}$ to clean the fouled membrane so as to elucidate the chemical cleaning protocols and cleaning efficiency. Flushing with ultra-pure (UP) water enabled the recovery of the fluxes of XLE and BW 30 membranes, as reflected by the mild decline $(\sim 1 \%)$ in the flux recovery for the XLE and BW 30 membranes. XLE and BW 30 membranes have exhibited consistent rejection capabilities throughout the 3-cycle filtration period. Conversely, NF 270 has failed to regain its rejection capability in the long run. Whereas, for chemical cleaning, the initial flux of NF 270 after cleaning with $0.1 \%$ NaOH rose dramatically compared to the initial flux in the first filtration cycle due to changes in the surface morphology. Conversely, NaOH cleaning had fully recovered the initial flux of the XLE and $B W 30$ membranes without compromise the rejection capabilities of both membranes. Based on the cleaning efficiency and permeate quality, it can be concluded that the $B W 30$ membrane with ultra-pure water (UP) and $\mathrm{NaOH}$ cleanings afforded the best and most consistent performance in the long run but HCl is not a preference for the cleaning of this membrane in the water reclamation due to the low flux recovery.
\end{abstract}

Keywords: Fouling; membrane cleaning; Palm Oil Mill Effluent (POME); wastewater reclamation

ABSTRAK

Rawatan POME dengan menggunakan membran boleh menyebabkan kekotoran membran berlaku kerana POME mempunyai bahan pepejal dan organik yang tinggi. Objektif kajian ini adalah untuk menilai prestasi dan penolakan tiga jenis membran (NF270, XLE dan BW 30) selepas pembersihan fizikal dan kimia. Proses pembersihan kimia telah dilakukan dengan menggunakan kimia $\mathrm{NaOH}$ dan kimia $\mathrm{HCl}$ untuk membersihkan membran yang kotor dan memberi gambaran tentang protokol pembersihan membran dan kecekapan pembersihan. Pembersihan dengan air UP membolehkan pemulihan fluks membrane XLE dan BW 30, seperti yang dicerminkan oleh penurunan yang sedikit ( 1\%) dalam pemulihan fluks untuk membran XLE dan BW 30. Membran XLE dan BW 30 telah mempamerkan keupayaan penolakan yang konsisten sepanjang tempoh 3-kitaran. Sebaliknya, NF 270 gagal mencapai keupayaan penolakannya dalam jangka panjang. Sebaliknya, untuk pembersihan kimia, fluks awal untuk membran NF 270 selepas pembersihan menggunakan 0.1\% NaOH meningkat secara dramatik berbanding dengan fluks awal dalam kitaran penapisan 1 akibat perubahan morfologi permukaan membran. Sebaliknya, pembersihan NaOH telah pulih sepenuhnya fluks awal membran XLE dan BW 30 tanpa mengganggu keupayaan penolakan kedua-dua membrane. Dari kecekapan pembersihan dan kualiti produk, dapat disimpulkan bahawa membran BW 30 dengan air ultra-tulen dan pembersihan kimia NaOH mempunyai prestasi yang konsisten dalam jangka masa panjang dan pembersihan kimia HCl kurang memuaskan sebagai agen pembersih disebabkan pemulihan fluks yang rendah.

Kata kunci: Kekotoran; pembersihan membrane; Kumbahan kilang minyak kelapa sawit (POME); penebus gunaan sisa air

\section{INTRODUCTION}

Malaysia is the second largest exporter of palm oil in the world after Indonesia (MPOB 2016). Several stages are involved in the extraction of palm oil, including operational processes such as sterilizing, striping, and threshing of bunches to free the palm fruit (Igwe and Onyegbado 2007). During the processes, more than $50 \%$ of the water will be discharged to the environment as palm oil mill effluent (POME) (Wah et al. 2002). POME has high turbidity and color resulting from its high content of organic matters and suspended solids (Shian et al. 2009). Most of palm oil mills in Malaysia use biological treatment involving aerobic, anaerobic, and ponding systems that need large areas and long treatment periods (Ahmad et 
al. 2003; Idris, Jami, and Muyibi 2010). Treatment of POME with evaporation technology has also been attempted but it incurs high expenses of energy at an estimated $1 \mathrm{~kg}$ of steam per $1 \mathrm{~kg}$ of water evaporated. Hence, in order to improve the quality of POME and reclaim the water, further treatments are required (Ahmad et al. 2003).

Nanofiltration (NF) and reverse osmosis (RO) membranes have been widely used in industrial wastewater treatment and reclamation. Permeate water from unconventional sources such as brackish water, polluted surface water, ground water, and secondary treated effluents has high quality and can be reused for many purposes such as cooling towers, boilers, and cleaning (Nghiem et al. 2010; Srisukphun et al. 2016). However, the use of membrane technology in advanced wastewater reclamations is impeded by the phenomenon of fouling. Membrane fouling refers to the decline in the flux of a membrane filter due to the deposition of impurities (foulants) on the membrane surface (Xu et al. 2006; Beyer, et al. 2010). Despite efforts to reduce fouling, for instance, by improvement of membrane properties, optimization of hydrodynamic conditions, and pretreatment of feed waters, fouling remains a major problem for membrane technologies (Lee \& Elimelech 2007).

Chemical cleaning and physical cleaning are commonly used techniques given their effectiveness in restoring the membrane flux (Al-amoudi and Lovitt 2007). Fouling materials can be removed either by physical means such as forward flushing, backwash, and scrubbing, or by chemical means such as cleaning in place (CIP), or chemical cleaning (Liu et al. 2001). Thus, membrane cleaning serves to remove the fouling layer on the membrane surface and is critical to the successful application of membrane technology. Membrane cleaning is required when permeate flux or salt rejection decreases by 10 to $15 \%$ (Srisukphun et al. 2016; Schippers 2015).

Many researchers have employed various chemical agents for cleaning in various filtration processes. Different chemicals have been used for CIP such as nitric acid, sodium hypochlorite, sodium hydroxide, and hydrochloric acid. Research has focused on flux recovery with chemical cleaning through synthetic chemicals. Al-Amoudi et al. (2008) studyied the cleaning with polyethylene glycol (PEG) as the feed. Chen et al. (2003) used secondary effluent collected from sewage treatment works as the feed. Simon et al. (2012) and Simon et al. (2009) employed pharmaceutically active compounds (PhACs) i.e. sulfamethoxazole and carbamazepine as the stock solutions for their study. The objective of this paper is to evaluate the performance of three types of membranes (NF270, XLE, and BW 30) after the physical and chemical cleaning for aerobic POME treatment. The membrane performance was monitored by flux drop and the permeate quality was compared with that from the standard boiler feed. Moreover, continuous chemical cleaning was conducted with sodium hydroxide $(\mathrm{NaOH})$ and hydrochloric acid $(\mathrm{HCl})$ to clean the fouled membrane so as to elucidate the chemical cleaning protocols and cleaning efficiency.

\section{MATERIALS AND METHODOLOGY}

MEMBRANES

The NF and RO membranes employed were the products of Dow FilmTech (USA). The XLE and BW 30 membranes are considered to brackish water reverse osmosis (BWRO) membranes whereas the NF 270 membrane is categorized as an NF membrane. The properties of the membranes used are listed in Table 1.

TABLE 1. Properties of the NF and RO membranes

\begin{tabular}{|c|c|c|c|c|c|}
\hline Membrane & MWCO (Da) & $\begin{array}{l}\text { Zeta potential at } \\
\text { pH } 9(\mathrm{mV})\end{array}$ & $\begin{array}{c}\text { Root mean square } \\
\text { (RMS) roughness }(\mathrm{nm})\end{array}$ & $\begin{array}{l}\text { Water permeability } \\
\text { coefficient }\left(\mathrm{L} / \mathrm{m}^{2} \mathrm{~h}\right)\end{array}$ & Contact angle $\left(^{\circ}\right)$ \\
\hline NF270 & $200-400$ & -37.50 & 3.265 & 21.18 & $36.6 \pm 13.17$ \\
\hline BW30 & $\sim 100$ & -2.30 & 23.445 & 6.54 & $56.2 \pm 20.57$ \\
\hline
\end{tabular}

\section{PREPARATION OF FEED SOLUTION}

The feed solution used in this study was collected from the aerobic ponding system at East Mill Sime Darby Palm Oil Plantation located at Carey Island, Selangor, Malaysia. The collected aerobically-digested POME was preserved in a cold room at temperature below $4^{\circ} \mathrm{C}$. During the membrane filtration, the collected aerobically-digested POME was diluted to around $150 \mathrm{mg} / \mathrm{L} \mathrm{COD}$ value to imitate the quality of POME after pretreatment.

\section{CROSS-FLOW MEMBRANE FILTRATION SYSTEM}

A laboratory bench-scale cross-flow membrane filtration system as shown in Figure 1 was used for this study. The commercial flat-sheet membranes were cut into rectangular shapes with an effective filtration area of $0.0042 \mathrm{~m}^{2}$ (excluding the area covered by the O-ring). The membrane was then laid on top of the CF 042 membrane holder (Sterlitech, USA) and tightened by a rubber O-ring. Before the membrane filtration, the newly-cut membrane was soaked in ultra-pure water and left for a day to remove the residual solvent/chemical from the membrane. In order to alleviate the impact of compaction, pre-filtration with ultra-pure water was first conducted at constant pressure of 6 bars for 1 hour until steady-state flux was achieved. Diluted aerobically-digested POME was then charged into a $10 \mathrm{~L}$ feed tank. The retentate was recycled into the feed tank in which the feed solution temperature was maintained at $27^{\circ} \mathrm{C}$ with a re-circulating water chiller 
(SPH-20, Malaysia). The applied pressure of the membrane filtration system was generated with a high-pressure pump (Blue Clean, BC 610, Italy) and controlled at 3 bars for all experiments. Two pressure gauges were used to indicate the operating pressure of the feed and retentate streams.

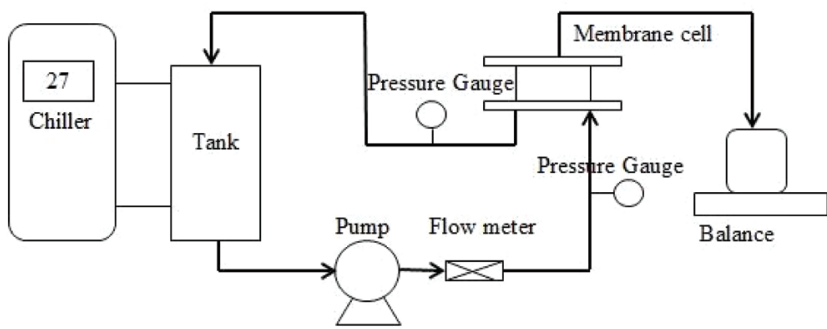

FIGURE 1. Schematic diagram of the bench-scale cross-flow membrane-filtration system

The permeate flux $(\mathrm{J})$ was determined by direct measurement of the permeate volume over time:

$$
J=\frac{V}{A t}
$$

where $\mathrm{J}$ is the permeate flux $\left(\mathrm{L} / \mathrm{m}^{2} \mathrm{~h}\right), \mathrm{V}$ is the permeate volume $(\mathrm{L}), \mathrm{A}$ is the membrane effective surface area $\left(\mathrm{m}^{2}\right)$, and $t$ is the permeation time $(\mathrm{h})$.

The membrane rejection $(\mathrm{R})$ was calculated with the following equation:

$$
R=\frac{C_{i}-C_{f}}{C_{i}} \times 100 \%
$$

where $\mathrm{R}$ denotes the membrane rejection (\%), $\mathrm{C}_{\mathrm{i}}$ and $\mathrm{C}_{\mathrm{f}}$ indicate the concentrations of the feed solution and of the permeate, respectively.

The analysis of membrane fouling was conducted for 6 hours while all the operating conditions were controlled. Fresh diluted aerobically-digested POME was added every 2 hours to maintain the concentration of the feed solution. To evaluate the propensity of membrane fouling, the relative flux reduction (RFR) was calculated as follows:

$$
R F R(\%)=1 \frac{J_{p}}{J_{w 1}} \times 100 \%
$$

where RFR is the relative flux reduction (\%), $\mathrm{J}_{\mathrm{P}}$ is the instantaneous permeate flux $\left(\mathrm{L} / \mathrm{m}^{2} \mathrm{~h}\right)$, and $\mathrm{J}_{\mathrm{W} 1}$ is the initial permeate flux $\left(\mathrm{L} / \mathrm{m}^{2} \mathrm{~h}\right)$.

After the filtration of the diluted aerobically-digested POME solution has lasted for 6 hours, membrane cleaning was conducted to determine the flux recovery of the membranes, which correlated to their defouling ability.

The flux recovery ratio (FRR) can be calculated from the water flux after membrane cleaning.

$$
R F R(\%)=1 \frac{J_{w 2}}{J_{w 1}} \times 100 \%
$$

where FRR is the flux recovery ratio (\%), $J_{W 2}$ is the permeate after cleaning $\left(\mathrm{L} / \mathrm{m}^{2} \mathrm{~h}\right)$, and $J_{W 1}$ is the initial permeate flux $\left(\mathrm{L} / \mathrm{m}^{2} \mathrm{~h}\right)$.

\section{MEMBRANE CLEANING PROCEDURE}

The laboratory bench-scale cross-flow recirculation unit depicted in Figure 1 was used to study the membrane cleaning. After the filtration of the diluted aerobicallydigested POME solution had lasted for 6 hours, cleaning was conducted to determine the flux recovery of the membranes, which correlated to their defouling ability. In this study, two types of cleaning were investigated i.e. physical cleaning with ultra-pure (UP) water and chemical cleaning with $\mathrm{NaOH}$ and with $\mathrm{HCl}$.

\section{PHYSICAL CLEANING PROCEDURE}

After the 6-hour filtration, UP water was circulated in the cross-flow membrane system to flush out the impurities deposited on the membrane surface for 1 hour. Afterwards, the membrane was used for the filtration of diluted tertiary POME again before the next cycle of cleaning was conducted.

\section{CHEMICAL CLEANING PROCEDURE}

For alkaline cleaning, after the 6-hour filtration, the membrane was soaked in $0.1 \% \mathrm{w} / \mathrm{w} \mathrm{NaOH}$ for 2 hours to remove the organic matters deposited on the membrane surface. Then, the membrane was rinsed with ultra-pure water for 15 minutes to remove the remaining $\mathrm{NaOH}$ by ensuring the $\mathrm{pH}$ of rinsed water was between 7 and 8 . Afterwards, the membrane was used for the filtration diluted tertiary POME again before the next cycle of cleaning was conducted. Likewise, for acid cleaning, the procedure was repeated by replacing the $\mathrm{NaOH}$ with $0.1 \% \mathrm{v} / \mathrm{v} \mathrm{HCl}$.

\section{ANALYTICAL METHODS}

The performance of each membrane in treating the diluted aerobically-digested POME was evaluated by assessing the quality of the permeate water based on parameters such as COD, total dissolve solids (TDS), phosphorus (P), color, turbidity, conductivity, and $\mathrm{pH}$. COD was measured by preheating the samples at $150^{\circ} \mathrm{C}$ in a Hach digital reactor RBC 200 (Hach Company, Colorado, USA) for two hours and analyzed with a DR3900 Benchtop spectrophotometer with RFID* Technology (Hach Company, Colorado, USA) in the high range (3-1500 mg/L). Phosphorus $(\mathrm{P})$ and color were measured based on the PhosVer 3 method and platinum-cobalt standard method with a DR3900 Benchtop spectrophotometer with RFID* Technology (Hach Company, Colorado, USA). Turbidity was measured with a $2100 \mathrm{~N}$ Laboratory Turbidimeter (Hanna, USA). Conductivity, TDS and $\mathrm{pH}$ of the permeate were measured with a HI 2550 Benchtop Meter (Hanna, USA). 


\section{MEMBRANE CHARACTERIZATION}

\section{SURFACE HYDROPHILICITY}

The membrane surface hydrophilicity was characterized by the contact angle with a drop-shape analysis gionometer, Model FM40Mk2 Easy Drop (Kruss GmbH, Germany) equipped with a high-speed camera, F046B IRF (Stingray, Germany). Prior to the contact-angle analysis, the membrane sample was adhered onto a glass slide with double-sided tapes to ensure that its top surface was upward and flat. A $0.15 \mathrm{~mm}$ syringe needle was used to provide a $3 \mu \mathrm{L}$ drop of RO water under ambient environmental condition. The acquired micrographs were analyzed with the DRO Pimage software to obtain the contact angle for the membrane sample. The reported contact angles were the average of three measurements taken at different locations on the membrane surface to minimize analytical errors.

\section{ZETA POTENTIAL}

The zeta potential of the membranes were examined in 0.1 $\mathrm{mM} \mathrm{NaCl}$ at $\mathrm{pH} 7$ with a surface zeta potential cell, Zeta Sizer Nano-ZS, (Malvern instruments Inc., UK) latex particles (hydrodynamic diameter between 300 and $350 \mathrm{~nm}$ ) as tracer particles. The membrane sample was cut into rectangular pieces $(7 \mathrm{~mm} \times 4 \mathrm{~mm})$ and stuck onto the sample holder with double-sided tapes to ensure that its top surface was upward and flat. The sample holder with the membrane sample attached on it was then inserted into a standard cuvette containing $0.1 \mathrm{mM} \mathrm{NaCl}$ at $\mathrm{pH} 7$ and placed into the surface zeta potential cell. The surface zeta potential was recorded by the Zetasizer software. The zeta potential of the membrane was repeated for three times to minimize the analytical error.

\section{ATOMIC FORCE MICROSCOPY (AFM)}

Membrane surface roughness and topography were investigated through scanning probe microscopy NTEGRA Prima (NT-MDT, Russia) in the semi-contact mode under ambient conditions. The membrane sample was scanned at a $10 \mathrm{~m}$ x $10 \mathrm{~m}$ scanning area by laser beams reflected by the cantilever tip, NSG 30 (NT-MDT, Russia) placed above the membrane surface. The reflected laser beams were then used to generate three-dimensional topographical images of the membrane surface. Three different spots on the membrane sample were measured, from which the average values were calculated.

\section{RESULTS}

\section{MEMBRANE FOULING STUDY WITH PHYSICAL CLEANING}

Figure 2 shows the membrane permeate flux for NF 270, XLE and BW 30 membranes undergoing 3 filtration cycles with 2 times of cleaning in between the $1^{\text {st }}$ and $2^{\text {nd }}$ cycles and between $2^{\text {nd }}$ and $3^{\text {rd }}$ cycles. The transition of flux from one cycle to another is the time spent on cleaning. From Figure 2, cleaning with UP water is found to recover the flux back or close to its initial flux level for each membrane. However, NF 270 is noted to have gradually lost its flux throughout the filtration cycles. The initial flux started at 43 LMH but dropped to $41 \mathrm{LMH}$ after the $1^{\text {st }}$ cleaning and further decreased to $39 \mathrm{LMH}$ after the $2^{\text {nd }}$ cleaning. As displayed in Table 2 , the $1^{\text {st }}$ and $2^{\text {nd }}$ cleanings managed to restore the $\mathrm{NF}$ 270 membrane flux to only $97 \%$ and $95 \%$ of its initial flux, a $5 \%$ loss was recorded in the flux after the $2^{\text {nd }}$ filtration cycles. Furthermore, the gradient of flux decline is observed to become progressively steep, indicating the worsening fouling severity. This suggests that physical cleaning with UP water was incapable of removing all the impurities deposited on the NF 270 membrane surface. Nevertheless, flushing with UP water enabled the recovery of the fluxes of XLE and BW 30, as reflected by the mild decline $(\sim 1 \%)$ in the flux recovery for the XLE and BW 30 membranes. Ang et al. ( 2011) used DI water to clean the RO membrane after a 17-hour filtration process to treat wastewater from a municipal treatment plant located in Wallingford, Connecticut, USA. Thus, cleaning the fouled membrane with DI water resulted in $32 \%$ cleaning efficiency. It is lower than the finding in this study. In their study, the membrane fouling was become irreversible after the 17-hour filtration. We can conclude in this study that diluted aerobic POME has a larger potential for reversible fouling.

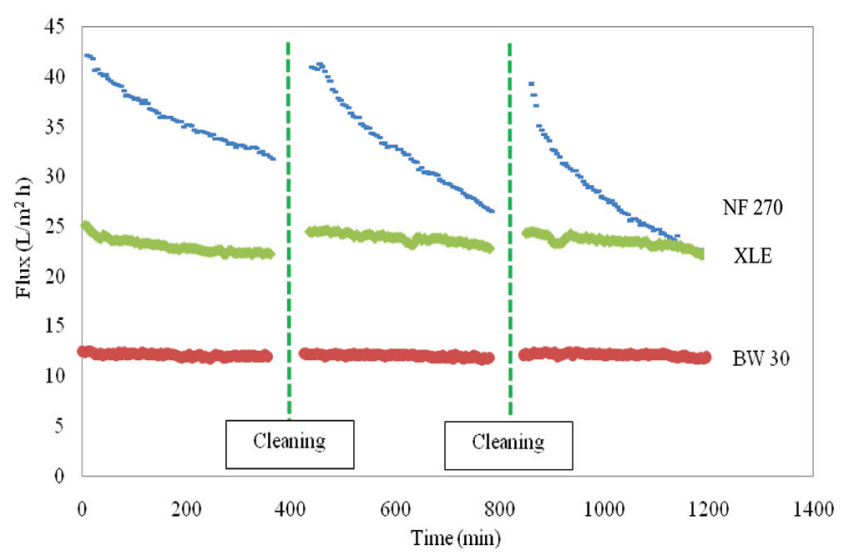

FIGURE 2. Profile of membrane permeate flux of each membrane with UP water cleaning in between filtration cycles

TABLE 2. Membrane flux recovery after each cleaning process with UP water

\begin{tabular}{lcc}
\hline Membrane & $1^{\text {st }}$ Cleaning (\%) & $2^{\text {nd }}$ Cleaning (\%) \\
\hline NF 270 & 97.22 & 93.28 \\
XLE & 97.50 & 96.93 \\
BW 30 & 98.17 & 97.03 \\
\hline
\end{tabular}

Apart from the flux performance, the capability of the membrane to regain and maintain its rejection after cleaning is another indicator for assessing the effectiveness of cleaning process. Table 3 shows that XLE and BW 30 membranes have exhibited consistent rejection capabilities throughout the 3- 
cycle filtration period. Conversely, NF 270 has failed to regain its rejection capability in the long run. The TDS and COD have exceeded the allowable limits for the boiler feed. Hence, it can be concluded that ultra-pure water was unable to completely remove the impurities on the NF 270 membrane surface which eventually led to the decline in performance. On the other hand, UP water cleaning was sufficient to recover the fluxes of the XLE and BW 30 membranes with a small loss.

TABLE 3. Permeate quality after each filtration cycle with ultra-pure water cleaning

\begin{tabular}{lcccccccccc}
\hline & & \multicolumn{3}{c}{ NF270 } & \multicolumn{3}{c}{ XWE } & \multicolumn{2}{c}{ BW30 } \\
\cline { 3 - 7 } & Feed & $1^{\text {st }}$ cycle & $2^{\text {nd }}$ cycle & $3^{\text {rd }}$ cycle & $1^{\text {st }}$ cycle & $2^{\text {nd }}$ cycle & $3^{\text {rd }}$ cycle & $1^{\text {st }}$ cycle & $2^{\text {nd }}$ cycle & $3^{\text {rd }}$ cycle \\
\hline COD (ppm) & 152.00 & 4.67 & 8.33 & 10.33 & 4.67 & 4.33 & 4.67 & 5.00 & 5.00 & 5.00 \\
TDS (ppm) & 374.67 & 213.00 & 245.00 & 248.00 & 20.63 & 21.03 & 22.30 & 24.00 & 24.37 & 26.23 \\
Color (PtCo) & 152.00 & 4.33 & 5.67 & 3.67 & 4.33 & 3.67 & 3.33 & 5.33 & 4.33 & 2.00 \\
Turbidity (NTU) & 18.23 & 0.23 & 0.23 & 0.26 & 0.12 & 0.12 & 0.14 & 0.21 & 0.18 & 0.19 \\
Conductivity $(\mu \mathrm{s} / \mathrm{m})$ & 747.00 & 425.33 & 465.67 & 483.67 & 41.07 & 42.80 & 43.40 & 48.60 & 45.63 & 51.60 \\
Chlorine (ppm) & 0.10 & 0.00 & 0.00 & 0.00 & 0.00 & 0.00 & 0.00 & 0.00 & 0.00 & 0.00 \\
pH & 7.68 & 7.62 & 7.79 & 7.86 & 7.98 & 7.81 & 7.72 & 7.98 & 7.84 & 7.85 \\
\hline
\end{tabular}

\section{MEMBRANE FOULING STUDY WITH CHEMICAL CLEANING}

\section{NAOH CHEMICAL CLEANING}

Figure 3 shows the membranes permeate fluxes for NF 270, XLE, and BW 30 undergoing 3 filtration cycles with 2 times of cleaning between the $1^{\text {st }}$ and $2^{\text {nd }}$ cycles and between $2^{\text {nd }}$ and $3^{\text {rd }}$ cycles. The transition of flux from one cycle to another is the time spent on cleaning. From the graph, it can be seen that cleaning with $\mathrm{NaOH}$ is capable of recovering the initial flux of each membrane except NF 270. After cleaning with $\mathrm{NaOH}$, the initial flux of NF 270 rose dramatically compared to the initial flux in the $1^{\text {st }}$ filtration cycle. Such a drastic change in flux suggests that the membrane had been damaged or the surface properties had been altered by $\mathrm{NaOH}$. The NF 270 membrane is known to contain a thin semi-aromatic piperazine-based polyamide active skin layer on a thick and porous polysulphone support (Nghiem et al. 2004). The observed change in the permeability of this membrane is likely secondary to the altered thin active skin layer, given its sensitivity to chemical cleaning (Simon et al 2013). Based on previous studies (Al-Amoudi et al. 2008; Simon et al 2012; Simon et al 2013; Kallioinen et al. 2016), chemical cleaning has been found to reduce negative charges of the NF 270 membrane and increase the membrane surface hydrophobicity. According to Simon et al. (2012), the high negative charges during the caustic cleaning possibly induces the polyamide structure of the NF270 membrane to become more open, which enhances the permeate flux. Furthermore, the final flux approaching the end of each filtration cycle is observed to decline. This again indicates that $\mathrm{NaOH}$ cleaning is inappropriate for the NF 270 membrane. Conversely, $\mathrm{NaOH}$ cleaning was demonstrated to be an effective cleaning approach for the XLE and BW 30 membranes as no noticeable loss in flux can be observed after each cleaning. The flux recovery after each cleaning shown in Table 4 suggests that $\mathrm{NaOH}$ cleaning had fully recovered the initial flux of the XLE and BW 30 membranes. Ang et al. (2011) found the effectiveness of $\mathrm{NaOH}$ in removing the fouling layer, as evidenced by the resultant cleaning efficiency of $79 \pm 3.9 \%$ in removing the mixtures of organic foulants. The authors, in their further study of dual step cleaning, showed the exceptional role of $\mathrm{NaOH}$ in enhancing the overall cleaning performance when introduced with other chemical agents, as attributed presumably to its ability to loosen the fouling layer. Hence, it can be concluded that $\mathrm{NaOH}$ was an effective cleaning agent in removing the impurities deposited on the XLE and BW 30 membrane surfaces.

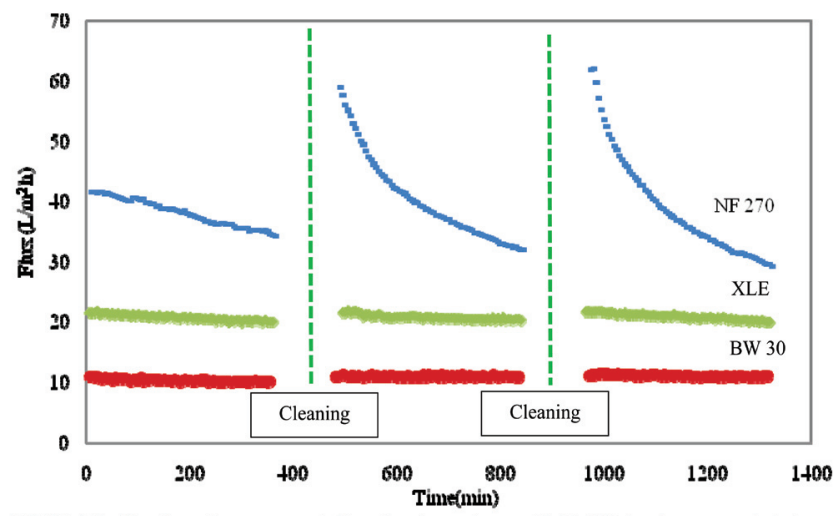

FIGURE 3. Profile of membrane permeate flux of each membrane with $\mathrm{NaOH}$ cleaning process in between the filtration cycles

TABLE 4. Membrane flux recovery after each cleaning process with $\mathrm{NaOH}$

\begin{tabular}{lcc}
\hline Membrane & 1st Cleaning (\%) & 2nd Cleaning (\%) \\
\hline NF 270 & 140.82 & 147.91 \\
XLE & 99.34 & 99.67 \\
BW 30 & 100.13 & 101.17 \\
\hline
\end{tabular}

The effect of $\mathrm{NaOH}$ cleaning on the NF 270 membrane is also reflected by the rejection capability. Table 5 shows that its rejection capability decreases over time, as could be associated with the change in the surface properties and with the blockage by impurities within the membrane pores. The TDS and COD have exceeded the allowable limits for the boiler feed. Conversely, XLE and BW 30 membranes have 
TABLE 5. Permeate quality after each filtration cycle with $\mathrm{NaOH}$ cleaning

\begin{tabular}{lrrrrrrrrrr}
\hline & \multicolumn{9}{c}{ NF270 } & \multicolumn{3}{c}{ XLE } & \multicolumn{3}{c}{ BW30 } \\
\cline { 2 - 10 } & Feed & $1^{\text {st }}$ cycle & $2^{\text {nd }}$ cycle & $3^{\text {rd }}$ cycle & $1^{\text {st }}$ cycle & $2^{\text {nd }}$ cycle & $3^{\text {rd }}$ cycle & $1^{\text {st }}$ cycle & $2^{\text {nd }}$ cycle & $3^{\text {rd }}$ cycle \\
\hline COD (ppm) & 154.00 & 4.00 & 6.33 & 8.33 & 3.33 & 4.33 & 4.67 & 3.00 & 3.33 & 4.00 \\
TDS (ppm) & 233.33 & 182.00 & 222.67 & 235.33 & 21.97 & 19.83 & 17.17 & 21.10 & 22.70 & 24.20 \\
Color (PtCo) & 253.00 & 6.67 & 10.67 & 11.67 & 5.33 & 4.33 & 5.00 & 1.33 & 3.00 & 3.67 \\
Turbidity (NTU) & 24.77 & 0.29 & 0.34 & 0.40 & 0.21 & 0.23 & 0.25 & 0.15 & 0.15 & 0.17 \\
Conductivity $(\mu \mathrm{s} / \mathrm{m})$ & 656.00 & 364.33 & 443.67 & 475.00 & 43.87 & 39.57 & 34.33 & 42.23 & 44.23 & 48.30 \\
Chlorine $(\mathrm{ppm})$ & 0.10 & 0.00 & 0.00 & 0.00 & 0.00 & 0.00 & 0.00 & 0.00 & 0.00 & 0.00 \\
pH & 7.78 & 7.55 & 7.71 & 7.75 & 7.55 & 7.37 & 7.65 & 7.55 & 7.44 & 7.57 \\
\hline
\end{tabular}

exhibited consistent rejection capabilities throughout the 3 -cycle filtration period. Therefore, it can be concluded that $\mathrm{NaOH}$ could be another potential cleaning agent for the XLE and BW 30 membranes since it does not react or alter their membrane characteristics.

\section{HCL CHEMICAL CLEANING}

Figure 4 shows the membrane permeate flux for NF 270, XLE and BW 30 undergoing 3 filtration cycles with 2 times of cleaning in between the $1^{\text {st }}$ and $2^{\text {nd }}$ cycles and between $2^{\text {nd }}$ and $3^{\text {rd }}$ cycles. The transition of flux from one cycle to another is the time spent on cleaning. From the graph, it can be seen that cleaning with $\mathrm{HCl}$ is capable of recovering the initial flux of each membrane except NF 270. After cleaning with $\mathrm{HCl}$, the initial flux of NF 270 rose dramatically compared to the initial flux in the $1^{\text {st }}$ filtration cycle. Such a drastic change in flux suggests that the membrane had been damaged or the surface properties have been altered by the $\mathrm{HCl}$. Furthermore, the final flux approaching the end of each filtration cycle is observed to decline. This again indicates that $\mathrm{HCl}$ cleaning is inappropriate for the $\mathrm{NF} 270$ membrane, given its undesirable reaction with the membrane. Table 6 shows that the flux recovery by percentage for NF 270 was the worst compared to cleanings with UP water or with $\mathrm{NaOH}$. A flux recovery of only $84 \%$ was recorded for the first cleaning, followed by $74 \%$ for the second cleaning. The rapid decline in the flux recovery suggests inefficient cleaning with $\mathrm{HCl}$. Furthermore, this phenomenon was also observed with the XLE membrane, for which after 2 filtration cycles, even though with $\mathrm{HCl}$ cleaning, the flux recovery was only $80 \%$. Hence, it can be said that $\mathrm{HCl}$ could not effectively remove the impurities deposited on the membrane surface of NF 270 and XLE. However, this finding was not observed with the BW 30 membrane, of which the flux recovery after $\mathrm{HCl}$ cleaning was as efficient as the cleanings with UP water or with $\mathrm{NaOH}$.

TABLE 6. Membrane flux recovery after each cleaning process with $\mathrm{HCl}$

\begin{tabular}{lcc}
\hline & 1st Cleaning (\%) & 2nd Cleaning (\%) \\
\hline NF 270 & 84.38 & 74.40 \\
XLE & 87.54 & 80.71 \\
BW 30 & 98.02 & 97.46 \\
\hline
\end{tabular}

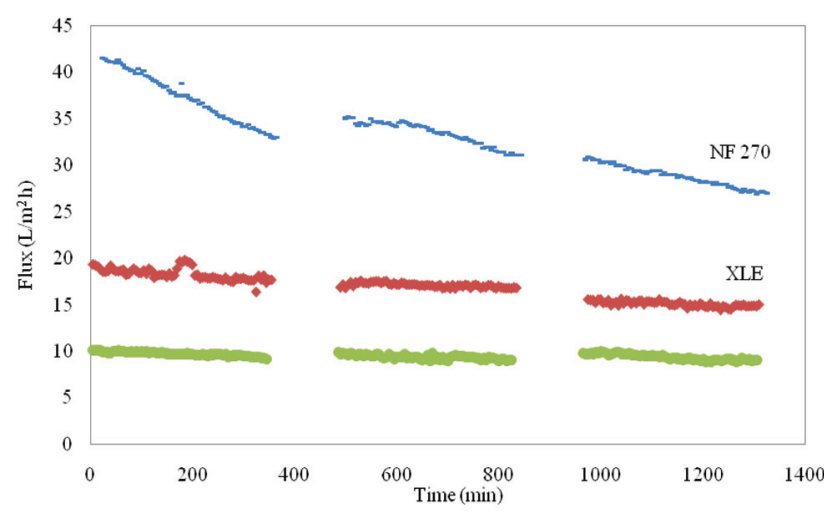

FIGURE 4. Profile of membrane permeate flux of each membrane with $\mathrm{NaOH}$ cleaning process in between the filtration cycles

Even though $\mathrm{HCl}$ was capable of recovering the flux for them BW 30 membrane, it degraded the membrane rejection property. As outlined in Table 7, the rejection of COD decreased substantially after the 3 filtration cycles. The trend was likewise exhibited by the NF 270 and XLE membranes. Therefore, it can be concluded that $\mathrm{HCl}$ is not a preferable cleaning agent for the purpose of membrane water reclamation.

\section{CONCLUSION}

Results from the long-term study with cleaning in between each filtration cycle reveal that cleaning is required to maintain the integrity of the membrane. Inappropriate use of the type of cleaning approach will result in degradation of the membranes and compromised membrane performance. The single-stage membrane-fouling study has indicated that after a 6-hour filtration period, cleaning should be started since the flux has dropped to 10 to $15 \%$ of its initial flux. From the cleaning efficiency and permeate quality obtained from the long-term membrane-fouling study, it can be concluded that the BW 30 membrane with ultra-pure water and $\mathrm{NaOH}$ cleanings offers the best consistent performance in the long run. Considering the cost of the cleaning materials $(\mathrm{NaOH})$ and the difficulty in handling and disposing of $\mathrm{NaOH}$, the use of UP water for cleaning is proposed for each 6-hour filtration period. This cleaning protocol will be adopted until the physical cleaning cannot recover at least $90 \%$ of the flux. Then, $\mathrm{NaOH}$ cleaning 
TABLE 7. Permeate qualities after each filtration cycle with $\mathrm{HCl}$ cleaning

\begin{tabular}{lrrrrrrrrrr}
\hline & \multicolumn{4}{c}{ NF270 } & \multicolumn{3}{c}{ XLE } & \multicolumn{3}{c}{ BW30 } \\
\cline { 2 - 10 } & Feed & $1^{\text {st }}$ cycle & $2^{\text {nd }}$ cycle & $3^{\text {rd }}$ cycle & $1^{\text {st }}$ cycle & $2^{\text {nd }}$ cycle & $3^{\text {rd }}$ cycle & $1^{\text {st }}$ cycle & $2^{\text {nd }}$ cycle & $3^{\text {rd }}$ cycle \\
\hline COD (ppm) & 154.00 & 4.00 & 6.33 & 8.33 & 3.33 & 4.33 & 4.67 & 3.00 & 3.33 & 4.00 \\
COD (ppm) & 148.33 & 3.33 & 7.33 & 10.33 & 2.67 & 5.67 & 7.67 & 3.67 & 4.67 & 7.33 \\
TDS (ppm) & 331.00 & 175.00 & 206.33 & 211.00 & 26.73 & 26.47 & 26.47 & 23.37 & 26.53 & 28.63 \\
Color (PtCo) & 534.00 & 2.00 & 5.00 & 4.00 & 3.00 & 3.67 & 3.67 & 0.00 & 2.33 & 3.33 \\
Turbidity (NTU) & 36.67 & 3.45 & 3.52 & 4.89 & 2.60 & 2.78 & 2.23 & 2.35 & 2.51 & 2.80 \\
Conductivity $(\mu \mathrm{s} / \mathrm{m})$ & 663.67 & 350.67 & 406.67 & 414.67 & 52.70 & 53.43 & 53.43 & 46.57 & 49.23 & 53.97 \\
Chlorine (ppm) & 0.10 & 0.00 & 0.00 & 0.00 & 0.00 & 0.00 & 0.00 & 0.00 & 0.00 & 0.00 \\
pH & 7.42 & 7.55 & 7.71 & 7.75 & 7.55 & 7.37 & 7.56 & 7.30 & 7.39 & 7.41 \\
\hline
\end{tabular}

will be performed once to remove the deposited impurities on the membrane surface. This is thereafter followed again by cleaning with UP water. This proposed cleaning protocol will not only ensure consistent long-term membrane performance but also extend the membrane lifespan and reduce the volume of the used $\mathrm{NaOH}$ solution for disposal.

\section{ACKNOWLEDGEMENTS}

The authors wish to gratefully acknowledge the financial support for this work by Geran Universiti Penyelidikan (GUP-2017-098) and Dana Penyelidikan Strategik (KRA2017-016).

REFERENCES

Ahmad, A.L., Ismail, S. \& Bhatia, S. 2003. Water recycling from palm oil mill effluent (POME) using membrane technology. Desalination 157(1-3): 87-95.

Ahmad, A.L., Ismail, S., Ibrahim, N. \& Bhatia, S. 2003. Removal of suspended solids and residual oil from palm oil mill rffluent. Journal of Chemical Technology \& Biotechnology 78(9): 971-978.

Al-amoudi, A. \& Lovitt, R.W. 2007. Fouling strategies and the cleaning system of NF membranes and factors affecting cleaning efficiency Journal of Membrane Science 303(1-2): 4-28.

Al-Amoudi, A., Williams, P., Al-Hobaib, A. S. \& Lovitt, R.W. 2008. Cleaning results of new and fouled nanofiltration membrane characterized by contact angle, updated DSPM, flux and salts rejection. Applied Surface Science 254(13): 3983-3892.

Ang, W.S., Tiraferri, A., Chen, K.L. \& Elimelech, M. 2011. Fouling and cleaning of RO membranes fouled by mixtures of organic foulants simulating wastewater effluent. Journal of Membrane Science 376(1-2): 196206.

Ang, W.S., Yip, N.Y., Tiraferri, A. \& Elimelech, M. 2011. Chemical cleaning of RO membranes fouled by wastewater effluent: Achieving higher efficiency with dual-step cleaning. Journal of Membrane Science 382(1-2): 100-106.
Beyer, M., Lohrengel, B. \& Nghiem, L.D. 2010. Membrane fouling and chemical cleaning in water recycling applications. Desalination 250(3): 977-981.

Chen, J. Paul, S. Kim, L. \& Ting, Y. P. 2003. Optimization of membrane physical and chemical cleaning by a statistically designed approach. Journal of Membrane Science 219(1-2): 27-45.

Idris, Munirat Abolore, Mohammed Saedi Jami \& Suleyman Aremu Muyibi. 2010. Tertiary Treatment of biologically treated palm oil mill effluent (POME) using UF membrane system: effect of MWCO and transmembrane pressure. International Journal of Chemical and Environmental Engineering 1(2): 109-112.

Igwe, J. C. \& Onyegbado, C.C. 2007. A review of palm oil mill effluent (POME) water treatment. Global Journal of Environmental Research 1(2): 54-62.

Schippers, J.C. 2015. 4-Day Advanced Course on PreTreatment, Membrane Fouling and Scaling. Rome.

Kallioinen, M., Sainio, T., Lahti, J., Pihlajamäki, A., Koivikko, K., Mattila, J. \& Mänttäri, M. 2016. Effect of extended exposure to alkaline cleaning chemicals on performance of polyamide (PA) nanofiltration membranes. Separation And Purification Technology 158: 115-123.

Lee, S. \& Elimelech, M. 2007. Salt cleaning of organicfouled reverse osmosis membranes. Water Research 41(5): 1134-1142.

Liu, Caothien, S., Hayes, J., Caothuy, T., Otoyo, T. \& Ogawa, T. 2001. Membrane Chemical Cleaning: From Art to Science. Pall Corporation, Port Washington, New York.

MPOB. 2016. Production of crude palm oil for the month of D ecember 2015. http://bepi.mpob.gov.my/index. php/statistics/production/135-production-2015/736production-of-crude-oil-palm-2015.html.

Nghiem, L. D., Schäfer \& Elimelech, M. 2004. Removal of natural hormones by nanofiltration membranes: measurements, modeling, and mechanisms. Environmental Science and Technology 38(6): 18881896.

Nghiem, L. D., Coleman, P.J. \& Espendiller, C. 2010. Mechanisms underlying the effects of membrane fouling on the nano filtration of trace organic contaminants. Desalination 250(2): 682-687. 
Shian, Y., Omar, M., Kadir, A.B. \& Tow, T. 2009. Bioresource technology biological kinetics evaluation of anaerobic stabilization pond treatment of palm oil mill effluent. Bioresource Technology 100(21): 4969-4975.

Simon, A, Nghiem, L. D., Le-clech, P., Khan, S.J. \& Drewes, J.E. 2009. Effects of membrane degradation on the removal of pharmaceutically active compounds (PhACs) by NF/RO filtration processes. Journal of Membrane Science 340: 16-25.

Simon, A, Price, W.E. \& Nghiem, L.D. 2012. Effects of Chemical Cleaning on the Nanofiltration of Pharmaceutically Active Compounds (PhACs). Separation and Purification Technology 88: 208-215.

Srisukphun, T., Chiemchaisri, C., Thanuttamavong, M. \& Chiemchaisri, W. 2016. Fouling and cleaning of reverse osmosis membrane applied to membrane bioreactor effluent treating textile wastewater. Environmental Engineering Research 21(1): 45-51.

Pui, W.W., Sulaiman, N.M., Nachiappan, M. \& Varadaraj, B. 2002. Pre-treatment and membrane ultrafiltration using treated palm oil mill effluent (POME). Songklanakarin Journal Science Technology 24: 891-898.

Xu, P., Drewes, J.E., Kim, T.U., Bellona, C. \& Amy, G. 2006. Effect of membrane fouling on transport of organic contaminants in NF/RO membrane applications. Journal of Membrane Science 279: 165-175.
*Teow Yeit Haan

Research Centre for Sustainable Process Technology, Faculty of Engineering and Built Environment, Universiti Kebangsaan Malaysia,

43600 UKM Bangi, Selangor Darul Ehsan, Malaysia

Mohd Syahmi Hafizi B Ghani

Programme for Chemical Engineering,

Faculty of Engineering \& Built Environment,

Universiti Kebangsaan Malaysia,

43600 UKM Bangi, Malaysia.

Abdul Wahab Mohammad

Research Centre for Sustainable Process Technology, Faculty of Engineering and Built Environment,

Universiti Kebangsaan Malaysia,

43600 UKM Bangi, Selangor Darul Ehsan, Malaysia.

*Corresponding author; email: yh_teow@ukm.edu.my

Received date: $16^{\text {th }}$ April 2018

Accepted date: $8^{\text {th }}$ August 2018

Online First date: $1^{\text {st }}$ October 2018

Published date: $30^{\text {th }}$ November 2018 